\title{
$\beta$-GLUCOSIDASE PRODUCTION OF TWO DIFFERENT ASPERGILLUS STRAINS
}

\author{
A. BRUMBAUER ${ }^{\mathrm{a}}$ and K. RÉCZEY \\ Department of Agricultural Chemical Technology, Technical University, Budapest, \\ H-1521 Budapest, P.O. Box 91. Hungary
}

(Received: 10 March 1999; accepted: 7 June 1999)

\begin{abstract}
$\beta$-Glucosidase has an important role in cellulose degradation by cleaving the cellobiose to glucose units. Supplementation of Trichoderma cellulase with exogenous $\beta$-glucosidase is needed to prevent the inhibition effect of cellobiose on exoglucanases and endoglucanases.

Production of $\beta$-glucosidase by Aspergillus niger and Aspergillus phoenicis has been investigated under different fermentations. Both strains were appropriate for enzyme production at high level under the applied conditions.

Cultivation of $A$. phoenicis on Mandels' medium containing a complex nitrogen source has resulted in a higher $\beta$-glucosidase activity than on Vogel's medium. In an air-lift fermenter $A$. phoenicis grew in the shape of beads with $1.41 \mathrm{IU} \mathrm{g}^{-1}$ cell-associated enzyme activity. The fungal pellets can be used as in situ immobilized enzyme preparation.

A. niger produced extracellular $\beta$-glucosidase at the level of $2.1 \mathrm{IU} \mathrm{m}^{-1}$ in stirred-tank fermenter with a yield of $210 \mathrm{IU} \mathrm{g} \mathrm{g}^{-1}$ glucose and productivity of $21.8 \mathrm{IU} \mathrm{l}^{-1} \mathrm{~h}^{-1}$.
\end{abstract}

Keywords: $\beta$-glucosidase, fermentation, A. niger, A. phoenicis

Enzymatic hydrolysis of lignocellulosic materials appears to be one of the most promising ways to produce renewable energy. In the hydrolysis of cellulose - the major component of plants - three main components of the cellulase enzyme system are acting simultaneously, i.e. 1,4- $\beta$-D-glucan-4-glucanohydrolases (endoglucanase, EC 3.2.1.4), 1,4- $\beta$-D-glucan-cellobiohydrolases (exoglucanase, EC 3.2.1.91) and $\beta$-1,4-glucosidase ( $\beta$-glucosidase, EC 3.2.1.21). The hydrolysis of insoluble native cellulose carried out by the synergistic action of exoglucanases and endoglucanases results in soluble cellodextrins and cellobiose; then $\beta$-glucosidase cleaves the cellobiose units to glucose (ENARI, 1987).

However Trichoderma reesei, which is one of the best cellulase producing microorganisms (MANDELS, 1975) secretes $\beta$-glucosidase at a low level. The cellobiose accumulating during the hydrolysis inhibits the activity of endoglucanase and

\footnotetext{
a Tel: 361463 1279, Fax: 361463 2598; E-mail: brumbauer@chem.bme.hu
} 
exoglucanase, decreasing the overall rate of hydrolysis (HOWELL \& STUCK, 1975, HSU et al., 1980, MAGUIRE, 1977). One the other hand cellobiose is not fermentable by Saccharomyces cerevisiae (WOODWARD \& WISEMAN, 1982). Therefor $\beta$-glucosidase activity should be kept at an optimal level related to cellulase in order to increase the saccharification rate of cellulose (STERNBERG et al., 1977, KHAN et al., 1985). One way to diminish the effect of cellobiose inhibition is the addition of exogenous $\beta$-glucosidase. Fungi belonging to the genus Aspergillus produce extracellular and cellassociated B-glucosidase in high yield, which is compatible with $T$. reesei cellulases (ALLEN \& STERNBERG, 1980, RÉCZEY et al., 1989, FLACHNER et al., 1999).

In this study Aspergillus phoenicis QM 329 and Aspergillus niger BKM F-1305 were examined, grown in shake flask and different kind of fermenter (air-lift, stirredtank fermenter). The aim of the work was to compare the extracellular and intracellular $\beta$-glucosidase production of the above Aspergilli under different fermentation conditions.

\section{Materials and methods}

\subsection{Microorganisms}

Aspergillus niger BKM F-1305 and Aspergillus phoenicis QM 329 were maintained on agar slant containing $5 \%$ malt extract, $18 \mathrm{~g} \mathrm{l}^{-1}$ bacto agar, at $30{ }^{\circ} \mathrm{C}$. After 14 days the spores were used for inoculation. The strains were obtained from the Culture Collection of the Dept. of Agricultural Chemical Technology, Technical University of Budapest.

\subsection{Media}

Inoculum was prepared the following way. One percent of spore suspension, containing $5 \times 10^{5}$ conidia $\mathrm{ml}^{-1}$, was used to initiate growth on $5 \%$ malt extract at 5.4-5.6 pH. The inoculum preparation was complete after 2 days at $31{ }^{\circ} \mathrm{C}$ and 350 r.p.m.

Two different nutrient media were used. The composition of Vogel's medium was $\left(\mathrm{g} \mathrm{l}^{-1}\right)$ : glucose 10 , proteose peptone 1.0 and citric acid 0.5 . After sterilization $2 \%$ Vogel's stock solution was added to the medium (VOGEL, 1964).

The composition of Mandels medium was $\left(\mathrm{g} \mathrm{l}^{-1}\right)$ : urea $0.3,\left(\mathrm{NH}_{4}\right)_{2} \mathrm{SO}_{4}$ 1.4, $\mathrm{KH}_{2} \mathrm{PO}_{4} 2, \mathrm{CaCl}_{2} 0.3, \mathrm{MgSO}_{4} 7 \mathrm{H}_{2} \mathrm{O}, 0.3$, proteose peptone 0.75 , yeast extract 0.25 , and trace elements were added to the medium in the following concentrations from $1 \%$ solutions: $3.3 \mathrm{ml} \mathrm{l}^{-1} \mathrm{FeSO}_{4} .7 \mathrm{H}_{2} \mathrm{O}, 1.1 \mathrm{ml} \mathrm{l}^{-1} \mathrm{MnSO}_{4}, 0.9 \mathrm{ml} \mathrm{l}^{-1} \mathrm{ZnSO}_{4}$ and $1.3 \mathrm{ml} \mathrm{l}^{-1}$ $\mathrm{CoCl}_{2}$ together with $10 \mathrm{~g} \mathrm{l}^{-1}$ glucose as carbon source (MANDELS \& WEBER, 1969). 


\section{3. $\beta$-Glucosidase production}

Shake flask cultures were made in $750 \mathrm{ml}$ Erlenmeyer flasks containing $150 \mathrm{ml}$ medium at $30{ }^{\circ} \mathrm{C}$ and 350 r.p.m. Inoculation was made with $15 \mathrm{ml}$ inoculum, described above. Samples were taken once a day to observe consumption of reducing sugar and production of $\beta$-glucosidase; $\mathrm{pH}$ was adjusted daily to 5.8-6.0. Three parallel flasks were run with both fungi.

The stirred-tank reactor was a 241 BIOSTAT U (Braun, Germany) fermenter with working volume of $181,0.5-1.0 \mathrm{v} / \mathrm{v} \mathrm{min}^{-1}$ aeration and $250-300$ r.p.m. stirring. The inoculum constituted $10 \%$ of the total volume. The initial $\mathrm{pH}$ was $5.8-6.0$ and it was adjusted to 6.0 after the first day, when it was let to go down to $\mathrm{pH} 3.0$, by addition of $10 \% \mathrm{NaOH}$ and $10 \% \mathrm{H}_{2} \mathrm{SO}_{4}$. Enzyme production was continuing on for 4 days, samples were regularly withdrawn and analysed for reducing sugar content and $\beta$-glucosidase activity. The calculated yield and productivity were based on extra- and intracellular $\beta$ glucosidase activity.

The air-lift fermenter was a Pyrex glass cylinder with a diameter of $70 \mathrm{~mm}$ and a height of $500 \mathrm{~mm}$ with $1200 \mathrm{ml}$ working volume. The bottom of reactor was a porous glass filter with a pore size of $40-90 \mu \mathrm{m}$. Agitation and aeration were performed by letting sterile air through the glass filter at a rate of $450-5001 \mathrm{~h}^{-1}$. Temperature was maintained at $30^{\circ} \mathrm{C}$, the initial $\mathrm{pH}$ was 5.2 , not adjusted. The air-lift fermenter was directly inoculated with conidia resulting in $10^{5}-10^{6}$ conidia $\mathrm{ml}^{-1}$ broth, determined with Bürker counting chamber.

One experiment was run with each Aspergillus strain in stirred-tank fermenter and in air-lift fermenter as well.

\subsection{Assays}

The substrate consumption was determined colorimetrically using dinitrosalicylic acid (DNS) reagent described by MILLER (1959). Samples of 0.1-0.5 ml were made up to $1.5 \mathrm{ml}$ with distilled water and $3 \mathrm{ml}$ of DNS reagent was added. The colour obtained after boiling the mixture for 5 min and diluting with $16 \mathrm{ml}$ of distilled water was measured at $550 \mathrm{~nm}$. The relative standard deviation of this method was $\leq 2.8 \%$.

Extracellular $\beta$-glucosidase activity was measured with $5 \mathrm{mmol} \mathrm{l}^{-1} \mathrm{pNPG}$ in $50 \mathrm{mmol} \mathrm{l}^{-1}$ citrate-buffer, $\mathrm{pH} 4.8$. One $\mathrm{ml}$ of substrate and $0.1 \mathrm{ml}$ of correspondingly diluted culture filtrate were incubated for $10 \mathrm{~min}$ at $50^{\circ} \mathrm{C}$ (NORKRANS, 1957). The reaction was stopped by addition of $2 \mathrm{ml} 1 \mathrm{~mol} \mathrm{l}^{-1} \mathrm{Na}_{2} \mathrm{CO}_{3}$. After cooling, $10 \mathrm{ml}$ of distilled water was added and the absorbance was read at $400 \mathrm{~nm}$. The activity was calculated as IU ml-1. One international unit is defined as one $\mu \mathrm{mol}$ p-nitrophenol produced by $1.0 \mathrm{ml}$ of enzyme per minute under the assay conditions. The assays were 
done in duplicate on each sample and the mean of the obtained values was used. Relative standard deviation was $\leq 2.0 \%$.

For cell-associated, intracellular $\beta$-glucosidase activity measurement the pellets were separated from the fermentation broth by filtration through a Büchner funnel. Wet pellets were directly used instead of $0.1 \mathrm{ml}$ of culture filtrate and treated as above. Intracellular activity was calculated as $\mathrm{IU}^{-1}$ wet pellet. The determinations were done in triplicate on each sample and the mean was used. Relative standard deviation was $\leq 4.5 \%$.

\section{Results and discussion}

\subsection{Extracellular $\beta$-glucosidase production on two different nutrient media}

The comparison of $\beta$-glucosidase production of Aspergillus phoenicis on two different nutrient media was carried out in shake flasks with $10 \mathrm{~g} \mathrm{l}^{-1}$ glucose as carbon source, inoculated by spore suspension. The results on Fig. 1A and 1B show that the reducing sugar concentration decreased in two days to zero on Mandels' medium while on Vogel's medium it lasted for three days. The starting $\mathrm{pH}$ 5.5-6.0 decreased to about 3 on both media but the reduction was much quicker on Mandels' medium. In both cultivations $\mathrm{pH}$ were adjusted to 6.0 , but only on Vogel's medium occurred a drastic $\mathrm{pH}$ drop again. The greatest difference between the two media was in extracellular $\beta$ glucosidase production. On Vogel's medium enzyme activity appeared in the fermentation broth after a rather long lag phase of 3 days, while on Mandels' medium it reached $0.9 \mathrm{IU} \mathrm{ml}^{-1}$ already on the first day of cultivation. Maximum activity, yield and productivity were five times higher on Mandels' medium than on Vogel's after 7 days of fermentation (Table 1).

Table 1

Comparison of extracellular $\beta$-glucosidase activity, yield and productivity on two different culture media

\begin{tabular}{lcc}
\hline Culture medium & \\
\hline Activity $\left(\mathrm{IU} \mathrm{m}^{-1}\right.$ ) & Vogel's medium & Mandels' medium \\
Yield (IU g glucose $)^{-1}$ & 0.46 & 2.38 \\
Productivity (IU $~^{-1} \mathrm{~h}^{-1}$ & 46 & 238 \\
\hline
\end{tabular}

${ }^{\text {a }}$ Cultivation was performed in shake flasks with $A$. phoenicis. 

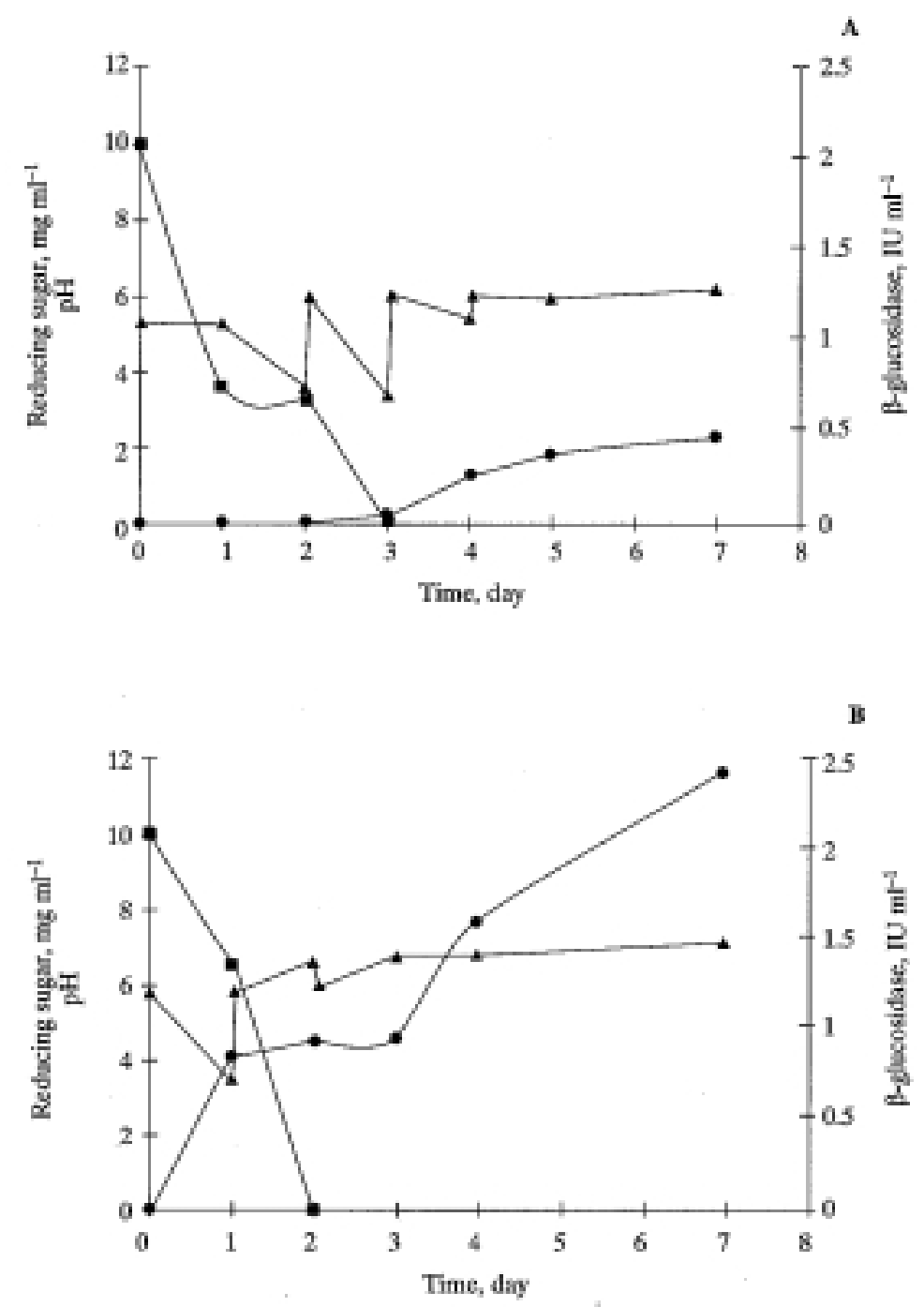

Fig. 1. Comparison of extracellular $\beta$-glucosidase production of $A$. phoenicis on different nutrient media. The cultivations were carried out in shake flasks with $10 \mathrm{~g}^{-1}$ carbon source. A: Cultivation on Vogel's medium. B: Cultivation on Mandels' medium. - - - extracellular $\beta$-glucosidase activity $\left(\mathrm{IU} \mathrm{ml}^{-1}\right.$ ) 


\section{2. $\beta$-Glucosidase production in shake flask and stirred-tank fermenter}

Strains, Aspergillus niger and Aspergillus phoenicis were cultivated in shake flasks and stirred-tank fermenter in order to compare the extracellular and intracellular ß-glucosidase production under the same circumstances. Mandels' medium was used with $10 \mathrm{~g} \mathrm{l}^{-1}$ glucose as carbon source. Both strains showed the same behaviour in shake flasks resulting in $2.80 \mathrm{IU} \mathrm{ml}^{-1}$ extracellular enzyme activity. The yield of both cultivation was $280 \mathrm{IU} \mathrm{g}^{-1}$ based on the added amount of glucose and $19.5 \mathrm{IU} \mathrm{l}^{-1} \mathrm{~h}^{-1}$ productivity was reached after a 6-day cultivation.

Whereas experiments performed in stirred-tank fermenter have shown different $\mathrm{pH}$ profile and carbon source utilization (Fig. 2A and 2B). A. phoenicis has consumed the carbon source somewhat slower but on the second day the reducing sugar concentration was zero in both experiments. In A. niger fermentation the $\mathrm{pH}$ dropped more rapidly and reached a minimum value of $\mathrm{pH} 1.6$ at $22 \mathrm{~h}$ of fermentation. Change in $\mathrm{pH}$ was not so drastic in A. phoenicis cultivation, where minimum was $\mathrm{pH} 2.4$ at $41 \mathrm{~h}$ of fermentation. Appearance of the $\beta$-glucosidase happened at about the same time, when $\mathrm{pH}$ has dropped under 3.0 and the carbon source was consumed. Final extracellular and intracellular $\beta$-glucosidase activity were 2.4-fold and 2.7-fold higher in $A$. niger cultivation than in $A$. phoenicis culture. The yield and productivity of $A$. phoenicis based on extra- and intracellular activity were only 38 and $39 \%$, respectively, related to A. niger (Table 2).

Table 2

$\beta$-Glucosidase production on Mandels' medium in stirred-tank fermenter

\begin{tabular}{|c|c|c|}
\hline Strains & A. niger & A. phoenicis \\
\hline Extracellular enzyme activity (IU ml-1) & 2.1 & 0.86 \\
\hline Inracellular enzyme activity (IU g ${ }^{-1}$ wet pellet) & 12.5 & 4.68 \\
\hline Yield ${ }^{\mathrm{a}}\left(\mathrm{IU} \mathrm{g}^{-1}\right.$ glucose $)$ & 185.8 & 70 \\
\hline Productivity $^{\mathrm{a}}$ (IU $1^{-1} \mathrm{~h}^{-1}$ ) & 29.9 & 11.7 \\
\hline
\end{tabular}

a Yield and productivity were based on extra- and intracellular enzyme activities 

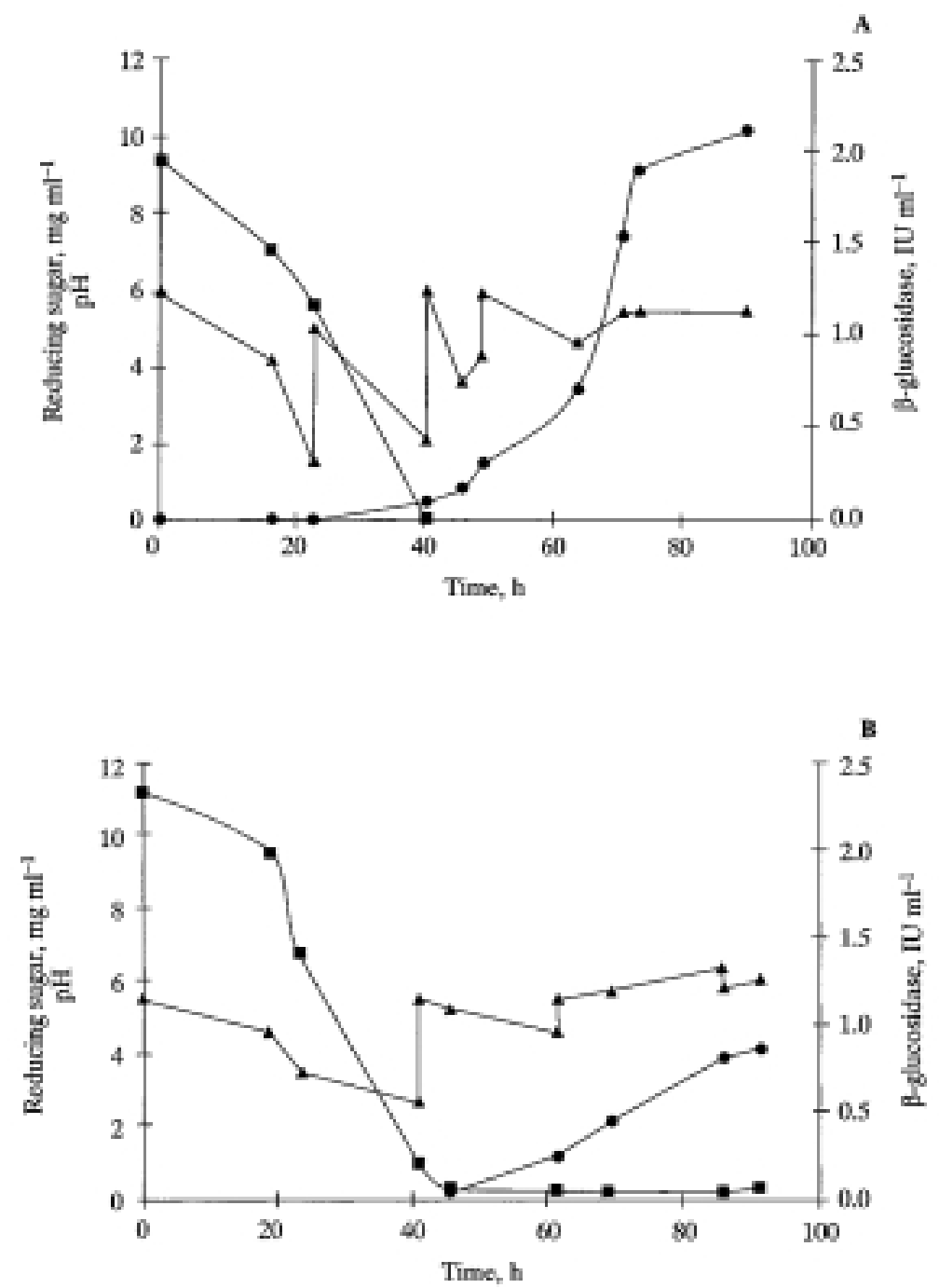

Fig. 2. Comparison of cultivation of A. niger and A. phoenicis in a 24-1 stirred-tank fermenter on Mandels' medium. The working volume was 181 with $10 \%$ of inoculation. The carbon source was glucose at $10 \mathrm{~g} \mathrm{l}^{-1}$. A: Cultivation of $A$. niger BKM F-1305. B: Cultivation of $A$. phoenicis QM 329. ———: reducing sugar ( $\mathrm{mg} \mathrm{m}^{-1}$ ); - $\mathbf{\Delta}-\mathrm{pH} ;-\bullet-$ : extracellular $\beta$-glucosidase activity $\left(\mathrm{IU} \mathrm{ml^{-1 }}\right)$ 

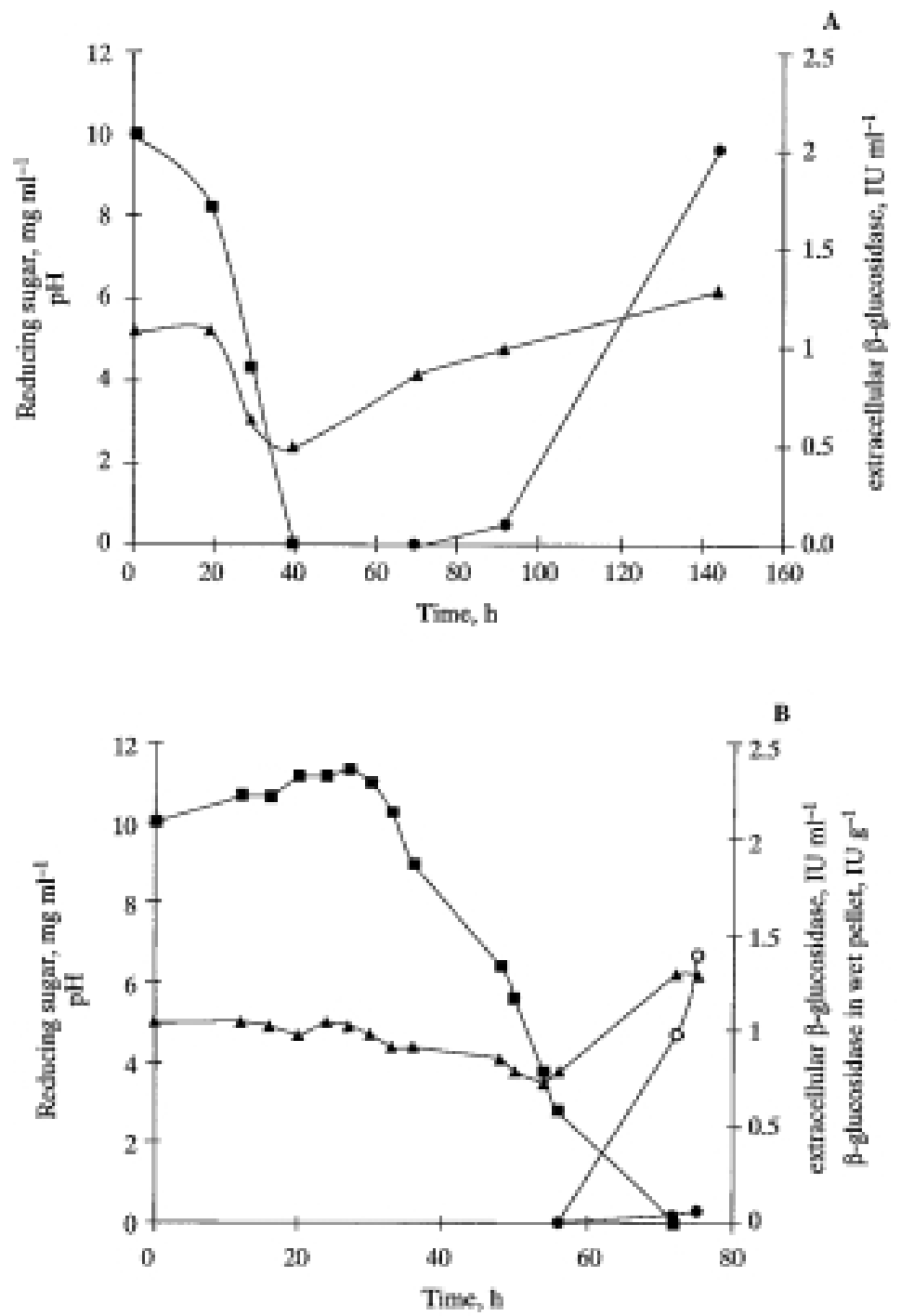

Fig. 3. Comparison of cultivation of A. niger and A. phoenicis in air-lift fermenter. The media were Mandels' and Vogel's medium, respectively. The working volume was $1200 \mathrm{ml}$ with $10 \mathrm{~g}^{-1}$ glucose as carbon source. A: Cultivation of $A$. niger BKM F-1305. B: Cultivation of A. phoenicis QM 329. ———: reducing sugar $\left(\mathrm{mg} \mathrm{ml}^{-1}\right) ;-\boldsymbol{\Delta}-: \mathrm{pH} ;-\bullet-$ : extracellular $\beta$-glucosidase activity $\left(\mathrm{IU} \mathrm{m}^{-1}\right)$; —O—: wet pellet activity ( $\mathrm{IU} \mathrm{g}^{-1}$ ) 


\subsection{Enzyme production in air-lift fermenter}

Both $A$. niger and $A$. phoenicis were cultivated in air-lift fermenter using Mandels' and Vogel's media, respectively (Fig. 3.). A. niger consumed glucose in $39 \mathrm{~h}$ while there was a rapid decrease in $\mathrm{pH}$ to 2.4 . In the $A$. phoenicis cultivation glucose was exhausted after $72 \mathrm{~h}$. During this cultivation $\mathrm{pH}$ dropped quite slowly and reached a minimum, $\mathrm{pH} 3.5$ in $54 \mathrm{~h}$. A niger has grown in filamentous and micropellet shapes producing $2.01 \mathrm{IU} \mathrm{ml}^{-1}$ extracellular $\beta$-glucosidase activity after 6 days of cultivation. It was not possible to detect intracellular enzyme activity owing to these growing forms. Under the same circumstances $A$. phoenicis has grown in the shape of beads with $1.41 \mathrm{IU} \mathrm{g}^{-1}$ wet pellet activity and only $0.08 \mathrm{IU} \mathrm{ml}^{-1}$ enzyme was detectable in the supernatant (Fig. 3A, Fig. 3B).

\section{Conclusions}

Both Aspergillus strains can produce $\beta$-glucosidase at high level to supplement cellulase of Trichoderma, corresponding to earlier studies (ALLEN \& STERNBERG, 1980, KERNS et al., 1987). However our results show that while A. phoenicis is recommended for immobilized enzyme production using air-lift fermenter, A. niger is recommended for soluble enzyme production in stirred-tank fermenter.

Cultivating A. niger in stirred-tank fermenter $12 \%$ and $56 \%$ higher extracellular enzyme productivity can be achieved than in shake flasks and in air-lift fermenter, respectively (Table 3 .).

Comparing the inoculation method of Aspergillus phoenicis, using the 2-dayinoculum on malt extract $37 \%$ higher productivity was achieved than by using a direct inoculation with conidia (Table 1 and 2.2. Chapter).

Table 3

Productivity of extracellular $\beta$-glucosidase activity with Aspergilli in different type of fermenters $\left(I U H^{-1} h^{-1}\right)$

\begin{tabular}{lcc}
\hline Strains & A. phoenicis & A. niger \\
\hline Shake flasks & 19.5 & 19.5 \\
Stirred-tank fermenter & 9.3 & 21.8 \\
Air-lift fermenter & 0.56 & 13.9 \\
\hline
\end{tabular}


National Research Fund of Hungary (OTKA F-26047), National Committee for Technical Research and Development (OMFB - EU-97-D10-112, OMFB-EU-98-E135) and Foundation of József Varga are gratefully acknowledged for their financial support.

\section{References}

AllEN, A. \& STERNBERG, D. (1980): $\beta$-Glucosidase production by Aspergillus phoenicis in stirred-tank fermentors. Biotech. Bioenging. Symp., 10, 189-197.

ENARI, T. M. (1987): Enzymatic hydrolysis of cellulose: Is the current theory of the mechanisms of hydrolysis valid? CRC Crit. Rev. Biotechnol., 5, 67-87.

FLACHNER, B., BRUMBAUER, A. \& RÉCZEY, K. (1999): Stabilization of $\beta$-glucosidase in Aspergillus phoenicis QM 329 pellets. Enzyme microb. Technol., 24, 362-367.

Howell, J. A. \& STUCK, J. D. (1975): Kinetics of Solka Floc cellulose hydrolysis by Trichoderma viride cellulase. Biotechnol. Bioengng., 17, 873-893.

HSU, T. A. GONG, C. S. \& TSAO, G. T. (1980) Kinetic studies of cellodextrin hydrolysis by exocellulase from Trichoderma reesei. Biotechnol. Bioengng., 22, 2305-2320.

KERNS, G., OKUNEV, O. N., ANANIN, V. M \& GOLOVLEV, E. L. (1987): Enhanced formation of $\beta$ glucosidase by Aspergillus niger VKMF- 20295 in fedbatch operation with frequently intermittent glucose addition. Acta Biotechnol., 7, 535-545.

KHAN, A. W., MEEK, E. \& HENSCHEL, J. R. (1985): $\beta$-Glucosidase multiplicity of activities and significance to enzymatic saccharification of cellulose. Enzyme microb. Technol., 7, 465-467.

MAGUIRE, J. R. (1977): Kinetics of the hydrolysis of cellulose by $\beta$-1,4-glucan cellobiohydrolase of Trichoderma viride. Can. J. Biochem., 55, 644-650.

MANDELS, M. (1975): Microbial sources of cellulase. Biotechnol. Bioengng. Symp., 5, 81-105.

MANDELS, M. \& WEBER, J. (1969): Production of cellulase. Adv. Chem. Ser., 95, 391-414.

MiLler, G. (1959): Use of dinitrosalicylic acid reagent for determination of reducing sugars. Anal. Chem., 31, 426-428.

NORKRANS, B. (1957): Studies of $\beta$-glucosidase and cellulose splitting enzymes from Polyporus annosus Fr. Physiol Plantarum, 10, 198-213.

RÉCZEY, K., PERSSON, I., TJERNELD, F. \& HAHN-HÄGERDAL, B. (1989): In situ immobilized ß-glucosidase from Aspergillus phoenicis QM329. Biotechnol. Techn., 3, 205-210.

STERNBERG, D., ViJAYAKUMAR, P. \& REESE, E. T. (1977) $\beta$-Glucosidase: Microbial production and effect on enzymatic hydrolysis of cellulose. Can. J. Microbiol., 23, 139-147.

VOGEL, H. J. (1964): Distribution of lysine pathway among fungi: Evalutionary implications. Am. Naturalist, XCVIII, 435 .

WOODWARD, J. \& WISEMAN, A. (1982): Fungal and other $\beta$-D-glucosidases - their properties and applications. Enzyme Microb. Technol., 4, 73-79. 